\title{
Reconciliation in Deuteronomy
}

H F van Rooy

(Noordwes Universiteit, Potchefstroom)

\section{ABSTRACT}

\section{Reconciliation in Deuteronomy}

The Book of Deuteronomy holds a central position in the Old Testament, and indeed in the Bible as a whole. It provides a summary of what the faith of Israel in the Old Testament is all about. It speaks about the covenant God made between himself and his people, about faithfulness to that covenant and of the implications of breaking the covenant. This covenant had implications not only for the way the people of Israel had to live as God's people in God's land, but also for the relationship among the members of the covenant. This article discusses the structure of the book of Deuteronomy, and then the way in which reconciliation appears in each of the different parts. The theme of reconciliation is not dealt with explicitly in all the passages discussed, but it does form a part of the subtext of the book of Deuteronomy. The people could only experience the Lord's blessings in the promised land after He had brought about reconciliation between Himself and them. To keep on experiencing the Lord's blessings, they had to remain faithfull to Him, obey his commandments and live within the boundaries He prescribed.

\section{INTRODUCTION}

The Book of Deuteronomy holds a central position in the Old Testament, and indeed in the Bible as a whole. It has even be called the centre of the Old Testament because it contains many themes that are very important in the Bible as a whole (cf. Clements 2001:xiii). One can compare its place in the Old Testament with the place of the Letter to the Romans in the New Testament. It provides a summary of what the faith of Israel in the Old Testament is all about. In it the whole revelation of God is seen as a unity (Von Rad 1975:222). It speaks about the covenant God made between himself and his people, about faithfulness to that covenant and of the implications of breaking the covenant. This covenant had implications not only for the way the people of Israel had to live as God's people in God's land, but also for 
the relationship among the members of the covenant people. Deuteronomy presents the blessings that would follow from keeping the covenant, but warns against the dire consequences of breaking the covenant (cf. Dt 28). Deuteronomy takes it seriously that the covenant can - indeed, will - be broken and points to the road of reconciliation between God and his people (cf. Van Rooy 1988b). In what follows I will first discuss the structure of the book of Deuteronomy, and then the way in which reconciliation appears in each of the different parts.

\section{THE STRUCTURE OF THE BOOK OF DEUTERONOMY}

It has long been recognised that the book of Deuteronomy is closely connected to the idea of the covenant in the Old Testament. The wellknown German Old Testament scholar, Gerhard von Rad (1975:20) linked the structure of the book to the liturgical movement of a covenant renewal ceremony at Shechem. To his mind the book consists of four parts (Von Rad 1958:34):

- Geschichtliche Darstellung der Sinaivorgänge und Paränese: Dt. 1-11;

- Gesetzesvortrag: Dt. 12-26,15;

- Bundesverpflichtung: Dt. 26,16-19;

- Segen und Fluch: Dt. 27ff.

Different scholars link the structure of Deuteronomy to a pattern related to the structure of Ancient Near Eastern vassal treaties. One example would suffice, namely the structure given by Craigie (1976:24):

- Preamble (1:1-5);

- Historical prologue (1:6-4:49);

- General stipulations (5-11);

- Specific stipulations (12-26);

- Blessings and curses (27-28);

- Witnesses (see 30:19, 31:19, 32:1-43).

Be that as it may, it is clear that many of the elements contained in the book are closely related to the idea of the covenant. This is accepted even by scholars who do not accept the idea that Deuteronomy is some 
kind of covenantal text, related to the Ancient Near Eastern treaties (cf. Millar 1998:41-47).

The book comes to us in the form of a number of speeches by Moses, directed at the people of Israel before they entered the promised land (cf. Wright 1998:2). The book itself had a long history with very old elements at the beginning of the process. Many of the elements in the book were reinterpreted and applied to new situations in the life of God's people.

The three main speeches start with introductions naming the parties involved and situating the speeches delivered to the people in the land of Moab, east of the river Jordan. In Deuteronomy 1:1-5 Moses is introduced where he is speaking to the people of Israel, delivering the message he was instructed by the Lord to proclaim to them. This happened east of the Jordan, forty years after the exodus from Egypt. The main points of this introduction reappear in the second introduction, in Deuteronomy 4:44-48. At the beginning of Deuteronomy 29 a third introduction appears. In most translations Deuteronomy 28 has 68 verses, with the following introduction to the third speech appearing in 29:1-2. In the Hebrew Bible, however, Deuteronomy 28 has 69 verses, with 29:1 of the translations taken not as part of the introduction, but as a superscript to the preceding section. This division of the Masoretic text has much in its favour and is most probably the best reading (cf. Van Rooy 1988a). If this is accepted, the superscript of 28:69 (MT) links up with the introduction at the beginning of the book, making Deuteronomy 1-28:69 a unity, containing the contents of the renewal of the covenant before the people entered the promised land. The original covenant is then the covenant the Lord made with the people at Horeb, such as described in Exodus 19-20, with the bulk of Deuteronomy (1-28) containing the renewed covenant.

If this is accepted, the main body of Deuteronomy can be regarded as a covenant document, with the following important elements (cf. Van Rooy 1977:233-256 for a detailed discussion):

- Introduction (1:1-5);

- Historical survey (1:6-4:40);

- Excursus on cities of refuges (4:41-43); 
- Introduction to the stipulations (4:44-48);

- Repetition of the covenant at Sinai (5);

- General stipulations about loyalty to the Lord (6-11);

- Specific stipulations (12-26);

- Covenant curses and blessing (27-28:68);

- Subscript (28:69 MT).

Deuteronomy 29 and 30 can then be regarded as a third speech of Moses, exhorting the people to remain faithful to the covenant, with the last four chapters as an appendix, containing diverse material, such as the succesion of Moses by Joshua, the song and blessing of Moses, and the description of his death. The issue of reconciliation in the last four chapters will not be dealt with in this contribution.

\section{RECONCILIATION IN THE HISTORICAL SURVEY (1:6- 4:40)}

The historical survey serving as an introduction to the covenant in the book of Deuteronomy is a history of reconciliation between the Lord and the people of Israel. The introduction to the book (1:1-5) contains a hint in this direction as well, with the two indications of dates. Verse 3 states that the speech of Moses was dated forty years after the exodus from Egypt. Verse 2 says that the normal duration of a journey from Mount Horeb to Kadesh Barnea is eleven days (cf. Wright 1998:22). Why did it take the people forty years to complete a journey of eleven days? The historical survey gives the reason, linking up with the history told in the three books before Deuteronomy in the Old Testament. Exodus and Numbers recount the sins of the people after the Lord delivered them from Egypt. Through their sins they broke the covenant the Lord made with them at Horeb. They were unfaithful to the covenant, and thus in need of reconciliation.

After the Lord entered into a covenant with them at Horeb, He commanded them to travel towards the promised land (1:19). After arriving at Kadesh Barnea, they sent twelve spies to survey the land and to bring a report back. Although the report was favourable about the land, the people were unwilling to invade the land, because of fear for the inhabitants of the land and a lack of trust in the Lord. As a result of 
their unwillingness, the Lord decided to punish the people, swearing that not one of the generation of the exodus would enter the promised land (1:20-36). The forty years of wandering through the desert was the result of their disobedience.

After forty years the Lord commanded them again to turn towards the promised land. This journey is then described in Deuteronomy 2-3. This description includes the defeats of Sihon and Og, as well as the division of the land east of the Jordan. The importance of this whole story is not so much the facts told, but rather the message behind the facts, viz., that the time of punishment had passed and that the Lord was about to make a new beginning with his people. He is a faithful God and they should remain faithful to him (Craigie 1976:94). He would again be their God and they should act as his people this time. In this sense the history told here is a history of reconciliation.

This is the point emphasised by Deuteronomy 4. As conclusion to the historical survey, Deuteronomy emphasises the responsibility of Israel as people of the covenant to obey the Lord (cf. Wright 1998:45). They are called the "people of his inheritance" (Dt 4:20), words pointing to the restored relationship between the Lord and his people. This chapter also points to the possibility that they might go astray again in the future, which would result in punishment, including exile from the promised land (4:27). Reconciliation with God will then again become possible, but repentence is highlighted as the prerequisite on their side. Reconciliation will begin from their side with the recognition of their evil ways, followed by repentence and conversion (4:29-31). This issue is taken up again in the section following the main contents of the covenant (Dt 29-30).

No god can be compared to the Lord (4:35). He chose the forefathers of the people because He loved them (4:37). They must answer by being obedient. A life in obedience will result in them receiving the blessing of the Lord in their lives.

\section{RECONCILIATION IN THE REPETITION OF THE COVENANT AT SINAI (5)}

The repetition of the covenant, especially the Ten Commandments as the core of the covenant stipulations, is no mere formality. It lies at the heart of the message of Deuteronomy (Craigie 1976:149). As is the 
case with the historical survey contained in the previous section, it is related to the history of the people since God had made the covenant with them at Sinai. That covenant was broken by the people when they refused to obey the Lord and enter the promised land. After the time of punishment spent in the desert, the Lord was making a new beginning and that new beginning included the renewal of the covenant broken by them. By taking them back to Sinai, the Lord was telling them that all was forgiven and that they could indeed make a new beginning together, as God and his people in the promised land. That is why Moses emphasised that the Lord was making a covenant anew with those present, and not with their fathers. The previous generation had passed away and their children would be God's children, because He had reconciled Himself with them. This new beginning had the same stipulations as the ones God had imposed on the people at Sinai - and it had the same end in mind. If they would only walk in the way of the Lord, they would live long and be prosperous in the promised land (5:32-33; cf. Wright 1996:93). The covenant is a relationship between God and his people and the covenant stipulations define the basic demands made to the people to remain in that relationship with the Lord (cf. Thompson 1974:112).

\section{RECONCILIATION IN THE GENERAL STIPULATIONS ABOUT LOYALTY TO THE LORD (6-11)}

The general stipulations about loyalty to the Lord starts of with the basic confession of the Israelites: "Hear, O Israel: The Lord our God, the Lord is one" (6:4). This confession, a statement of a fundamental monotheisic dogma (Craigie 1976:169), would form the basis of the life of the people in the promised land. If they remembered this confession and lived according to it, they would keep on receiving the blessings of the Lord. If, however, they did not keep it in mind, the danger of serving the gods of the land would always be a threat. Disobdience could result in the provoking of the anger of the Lord, with dire consequences for them and their children. They had to remember that the Lord had chosen them because He loved them (Brown 1993:97) .

This section reminds them of their disobedience in the past. This disobedience resulted in the wandering in the desert. The Lord used the time in the wilderness to teach them that they should always live from the Lord's words, as man can not live by bread alone (8:2-5, cf. 
Clements 2001:38-39). Their history was a history of rebellion, and that provoked the Lord's anger, so that He wanted to destroy them (9:7-8, cf. Wright 1998:134-135). They made themselves an idol in the form of a calf, and this implied that they broke the covenant with the Lord. That is why Moses shattered the tablets containing the Ten Commandments, making it clear that they had broken off their relationship with the Lord. To restore this relationship, they needed to be reconciled with the Lord, and Moses acted to bring about this reconciliation (9:19, cf. Craigie 1976:196). When they refused to enter the promised land, they again separated themselves from God, and again Moses had to intercede (9:25-29). In the end, before the time of this speech of Moses, God reconciled Himself with them, and as a sign of the restored relationship He gave Moses two new tablets containing the Ten Commandments. On account of the reconciliation between God and his people, the had to live within the boundaries of the restored covenant. This is spelt out very clearly in 10:12-22 (cf. Brown 1993:138). They have to love the Lord, because He loved them first. The reconciliation between Him and them had implications for their relationship with one another. He would defend the ones who are powerless, the orphans, the widows and the aliens, He would not accept bribes, but would act impartialy.

In the final section of the exhortation to remain loyal to the Lord, Moses warned them against the worship of other gods (11:16). Idolatry would again estrange them from God (Thompson 1974:154). They had to obey the Lord, as that was the only way to keep their relationship with Him intact.

\section{RECONCILIATION IN THE SPECIFIC STIPULATIONS (12-26)}

In the general stipulations of the covenant provisions occur that deal with reconciliation between God and his people, as well as among the people themselves. The whole set of stipulations has as purpose to spell out the way in which the people of Israel had to live within the boundaries of a reconciled relationship with God.

As far as reconciliation with God is concerned, Deuteronomy 12 and 13, the first chapters of specific stipulations, are of special importance. The issue of their relationship with God is dealt with first, 
before the prescriptions for their lives in general are given (cf. Brown 1993:144). Deuteronomy 12 deals with the issue of one place of worship. That would be the place of special communion between God and his people, within the reconciled relationship. At that one place the people had to worship the Lord in the centralised cult. Obedience in this regard would ensure the continuance of the reconciled relationship, whereas disobedience would annul that relationship. Deuteronomy 13 links up with this and gives provision for the action of the people when a prophet or a close relation or a rebellious city wanted to lead the people away from the Lord. This could be very dangerous for the reconciled relationship. In such an instance severe action was necessary to protect the relationship between God and his people. Such a prophet or family member, or even a whole city, had to be put to death. This demonstrates the importance of keeping the reconciled relationship between the Lord and his people intact.

As far as reconciliation between members of God's people is concerned, the following passages should be considered: Deuteronomy $15: 1-18 ; 16: 18-20 ; 17: 8-13 ; 19 ; 20: 1-9 ; 22: 13-30 ; 24: 1-4$ and 25:1-3. These passages indicate that when the relationship among members of the people of God was disturbed, steps should be taken to bring about reconciliation in one form or another. Such reconciliation could include punishment for a transgressor.

Deuteronomy 15:1-18 deals with different instances where inequalities arose among the people of God, through debt or enslavement. All the members of the people of God had an equal share in the relationship with Him. This had implications for the way in which they had to deal with social unequality. There should be no poor among God's people (15:4). To bring this about, creditors had to write off the loans made to poor people at the end of every seven years (15:111). The approach of this seventh year should also not keep people from lending money to their poor neighbours. The worst consequence of poverty was enslavement of an Israelite, when the poor person had to sell himself or herself to a fellow Israelite to get out of debt. After six years of service this Israelite slave had to be set free to restore the equality between Israelites.

Quite a number of the covenant stipulations deal with the institution and function of judges in Israelite society. They had an 
important function to settle differences and to judge cases, and thus bringing about reconciliation in society. Deuteronomy 16:18-20 instructs the people to appoint judges, and states that the judge should judge fairly, not taking bribes or showing partiality (cf Wright 1998:205). If the people followed justice, they would keep on possessing the land the Lord gave them. Deuteronomy 17:8-13 makes provision for those instances where a case is too difficult for the local judges to decide on. In these instances they had to submit the case to the Levites and judges at the central sanctuary. They had to decide the case and their decision was final (cf Wright 1998:206-207). Deuteronomy 19:15-21 contains stipulations about witnesses in the court. A person may not be convicted on the testimony of just one person, to prevent the misuse of the courts (cf. Wright 1998:224-225). False witnesses had to be dealt with severely. If it was proven that a person gave a false testimony, that person must receive the punishment that the person falsely accused would have received. Corporal punishment was a possibility in some instance, but its use was restricted to prevent people being degraded (Dt 25:1-4).

Deuteronomy 19:1-13 deals with the usage of cities of refuge (cf Rofé 2002:121-147). This institution can be seen as an impressive achievement in the field of bringing about justice (Rofé 2002:121). A murderer received the death penalty, and that could have been executed by the avenger of blood, a relative of the murdered person. If someone killed another unintentionally, by accident, such a person could flee to the nearest city of refuge to save his life. If, however, it is established that death was caused not by accident, but was intentional, the elders of the city of refuge had to hand the murderer over to the avenger of blood. In this way reconciliation for murder could be brought about. A related issue is dealt with in Deuteronomy 21:1-9, viz., atonement for an unsolved murder. Verse 8 contains one of the two occurrences in Deuteronomy of the verb used for atonement in Hebrew (rpk, cf Averbeck 1997 for the use of this verb), where the elders of the city had to ask the Lord to accept a particular sacrifice as atonement for the people. The stipulation deals with the matter of an unsolved murder, where the nearest city to the point where the body was found, had to be established. The elders of that city had to take a heifer to valley that has not been ploughed or planted. There they had to break the heifer's neck 
and wash their hands over this heifer's body. In this way reconciliation could be affected for the dead person's family.

Some of the passages to be discussed deal with marital issues (cf Rofé 2002:169-192). In the instances where a wrong was done in this regard to someone, usually a lady, reconciliation must be affected. This could happen in different ways. If a man slanders his wife after the marriage saying that she was not a virgin, and it is demonstrated that he is wrong, he had to pay a fine of 100 shekels to the girl's father and was not allowed to divorce her (Dt 22:13-19). If she was guilty, she had to be stoned (22:20-21). In instances of adultery or rape, the usual punishment was death (22:22-27). The only exception was the rape of a virgin not pledged to be married, where the man had to marry the girl. An extensive discussion of this passage can be found in Pressler (1993:21-43). Deuteronomy 24:1-4 contains stipulations about divorce (the giving of a certificate of divorce) and the prohibition to remarry a divorced woman (cf Pressler 1993:45-62).

\section{RECONCILIATION IN THE CURSES AND BLESSINGS (27-28)}

The curses and blessings form an essential part of the covenant document reflected in the book of Deuteronomy. This is quite clear from the introduction to the curses and blessings in Deuteronomy. At the beginning of Deuteronomy 27 Moses commanded the people to write the law on large stones and to set them up as a memorial in the promised land. After entering the land, they had to built an altar as well and to offer fellowship offerings to the Lord (27:1-7). They had to follow this up with a ceremony on Mount Ebal and Mount Gerizim, pronouncing curses on those who did not keep the laws of the Lord (27:15-26). If the people did not live within the boundaries set by the covenant, they would not continue to be a people reconciled with God, and consequently they would not enjoy his blessing, but rather suffer from his curse.

In Deuteronomy a whole list of blessings and curses is given, making it clear what the consequences will be of a life of obedience and of a life of disobedience. To enter the promised land, God had to bring about reconciliation between Himself and them. To continue to enjoy the fruits of this reconciled relationship, they had to live a life of 
obedience. If they did not do that, the former reconciliation would not guarantee their future fellowship with God.

\section{RECONCILIATION IN THE EXHORTATION TO REMAIN FAITHFULL TO THE COVENANT (29-30)}

The exhortation appearing in Deuteronomy 29 and 30 recapitulates many of the elements of the previous main section of the book. It refers to the history of their journey to the point where the people were about to enter the promised land (29:1-8). It restates the call that the people must be loyal to the Lord alone and warns against the possibility of apostacy (29:9-18). It points out the consequences of disobedience, which may even result in the loss of the promised land (29:19-29).

At the beginning of Deuteronomy 30 a section appears that is very important for the subject of reconciliation. What would happen if they did sin in the future and in doing so annulled the covenant with the Lord? There would then be another opportunity for reconciliation with God (30:1-10). The prerequisite would be repentence on the side of the people. They would have to return to the Lord with their whole heart and obey Him. If they did that, He would return to them and reconcile Himself with them again. They would then become his people again and He would be their God, protecting and blessing them (cf Van Rooy 1988b). At the end of the third speech (30:11-20) the people were warned to make a choice. They had to choose between life and death. If they chose to obey the Lord, the reconciled relationship with Him would endure, bringing life. Disobedience would, however, result in death.

\section{CONCLUSION}

The theme of reconciliation is not dealt with explicitly in all the passages discussed, but it does form a part of the subtext of the book of Deuteronomy. The people could only experience the Lord's blessings in the promised land after He had brought about reconciliation between Himself and them. To keep on experiencing the Lord's blessings, they had to remain faithfull to Him, obey his commandments and live within the boundaries He prescribed. If they failed to do that, the result would be punishment. For the restoration of the broken relationship, reconciliation was possible, but then on the condition that they would repent and return to the Lord. 


\section{Consulted literature}

Averbeck, R E 1997. rpk. NIDOTT 2, 689-710.

Brown, R 1993. The message of Deuteronomy. Leicester: Inter-Varsity Press.

Clements, R 2001. The Book of Deuteronomy (Epworth Commentaries). Peterborough: Epworth.

Craigie, P C 1976. The Book of Deuteronomy (New International Commentary on the Old Testament). Grand Rapids: Eerdmans.

Millar, J G 1998. Now choose life. Theology and Ethics in Deuteronomy (New Studies in Biblical Theology). Leicester: Apollos.

Pressler, C 1993. The view of women found in the Deuteronomic family laws (BZAW 216). Berlin: De Gruyter.

Rofé. A 2002. Deuteronomy. Issues and interpretation (Old Testament Studies). Edinburgh: Clark.

Thompson, J A 1974. Deuteronomy (Tyndale Old Testament Comentaries). London: Inter-Varsity Press.

Van Rooy, H F 1977. ' $n$ Verelyking van die struktuur van die buite-Bybelse staatsverdrae - met besondere aandag aan die Sefire-verdrae - met die struktuur van Deuteronomium. D.Litt.-proefskrif. PU vir CHO, Potchefstroom.

-, 1988a. Deuteronomy 28, 69 - Superscript of subscript. Journal of Northwest Semitic Languages 14, 215-222.

-, 1988b. Verbond en vergewing. Hervormde Teologiese Studies 44(4), 864-882.

Von Rad, G 1958. Das formgeschichtliche Problem des Hexateuch, in Von Rad, G. Gesammelte Studien zum Alten Testament. München: Kaiser, 9-86.

-, 1975. Old Testament Theology I. London: SCM.

Wright, C 1998. Deuteronomy (New International Biblical Commentary). Peabody: Hendrickson. 